\title{
Abundance of microarthropods population in different sites of Midnapore east coast of West Bengal, India
}

\author{
Mrinal Kanti Dey ${ }^{1 *}$, Ashis Kumar Hazra ${ }^{2}$ \\ ${ }^{1}$ Senior Environmentalist, PM CR Dey Memorial Society, West Bengal, India \\ ${ }^{2}$ Zoological Survey of India, New Alipore, Kolkata 700053, India \\ *Correspondence E-mail : mrinalkantidey86@gmail.com;pmcrdeymsociety@gmail.com
}

\begin{abstract}
Soil represents one of the most important reservoirs of biodiversity. Soil fauna is an important reservoir of biodiversity and plays an essential role in several soil ecosystem functions; furthermore it is often used to provide soil quality indicators. An ecological study of microarthropods communities from East Midnapore coast, West Bengal, India was undertaken. Four different biotopes were studied over the course of 30 months. A total 44 species of soil microarthropods were studied in details with regard to seasonal population fluctuation, variation in their community structure, relationship with physiochemical parameters of soil, life cycle pattern and their functional role in the ecosystem.
\end{abstract}

Keywords: Soil microarthropods; Population fluctuation; Diversity

\section{Introduction}

The word soil is derived from the latin word "Solum" means floor. Natural activities like wind, water flow etc. for hundreds and thousands of years upon the rocks initiates the process of disintegration of rocks gradually resulting in very small particles. These particles after mixing up with organic matters of soil support like many soil organisms (Thompson and Troch 1979) Living organisms were reported to have established themselves very early in the process of decomposition of parent materials, which indicates that organic decomposition is also associated with the early stage in the soil formation. The organic content of the soil in the embryonic phase of development has been found to be very low as the vegetation and its associated fauna do not develop in high densities (Newel K.1984). During these initial stages also, the products of organic decomposition occur along with inorganic decomposition resulting into formation of chemical complexes already formed not easily separable from components of solid however, as both of these decomposition process occur side by side and in combination, the size of soil particles, and the spaces between them, become smaller leading to the increase in water- holding capacity of soil. This together with the increasing amount of plant nutrients and organic materials, allow the soil to support higher plant life, such as grasses and other shrubs as the protective covering through the binding action of the root system and thereby promotes the greater stability of soil structure. These conditions favour the development of rich soil microflora and microfauna (Monleon and Kermit 1996). Mircoarthropods and microflora constitute two major groups of decomposer organisms of soil litter of any natural or near to natural ecosystem. They are closely associated with each other as in natural ecosystem functioning where the microarthropods feed upon the microflora 
(Luxton 1966) (Mangroves are salt tolerant forest ecosystems of tropical and subtropical interdial coastal regions near river mouth. A mangroves ecosystem constitutes a reservoir, refuge feeding ground and nursery for many useful and unique plants and animals confined to these regions. The mangroves provide an important nutrient input and primary energy source for many estuaries. Mangrove ecosystem, the ecosystem dominated by interdial salt tolerant halophytic vegetation enjoying the influences of two high and two low tides a day offers a unique environment for aquaculture development (Chakraborty and Choudhury 1995). In India a large amount of scientific literature is now available dealing with different aspects of mangrove ecosystem. Even then, while formal aspects of this ecosystem are relatively well studied, the faunal elements and their ecological implications are rather disparately presented. In most of the cases either planktons or macrobanthic fauna of the intertidal area of the mangroves have been presented. Interestingly, terrestrial faunal elements, many of which inhabit terrestrial water border zones vis-à-vis mangroves are practically neglected for study. Keeping the above facts in mind, the present research work has been undertaken to study the ecology of soil microarthropods on East Midnapore coast West Bengal, India, which include a blend of terrestrial and mangroves microfauna. The ecological study includes population dynamics, distribution, species composition and community interaction of different soil microarthropods of selected study sites of their environment.

\section{Materials and Method}

Method of Samplings, Extraction of faunal, preservation and Identification

Soil samples were collected with the help stainless steel corer (Inner -cross sectional diameter is $8.5 \mathrm{sq} / \mathrm{cm}$ ) from a depth of $5 \mathrm{~cm}$ per plot at monthly interval (Curry 1971) during July 2003- to December 2005. The Samples were collected from three sub-sampling sites of each study sites [Junput( $21^{\circ} 43$ '29.56" $\mathrm{N}$ $87^{\circ} 48^{\prime} 41.88^{\prime \prime}$ E) Dadanpathrabhar

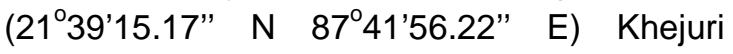
$\left(21^{\circ} 58^{\prime} 36.66^{\prime \prime} \mathrm{N}, 87^{\circ} 47^{\prime} 09.58^{\prime \prime} \mathrm{E}\right)$, Nayachar $\left.\left(21^{\circ} 58^{\prime} 36.68^{\prime \prime} \mathrm{N}, 88^{\circ} 04^{\prime} 49.10^{\prime \prime} \mathrm{E}\right)\right]$. Therefore, nine-corer samples were collected from each study site.

In this study, to extract the soil fauna, the apparatus used was slightly modified as that of (Macfadyen 1955). The collected fauna were then stored out into different groups under stereoscopic binocular microscope, counted and preserved in glass vials containing $70 \%$ alcohol for further study.

Abundance (A), Relative abundance (RA)

Abundance $(A)$, Relative abundance (RA) of different species were calculated using following expressions:-

$A=n i / X$

$\mathrm{RA}=(\mathrm{ni} / \mathrm{N}) \times 100$

Where $X=$ Total number of sampling unit $n i=$ Number of individuals of ith species.

$\mathrm{N}=$ Total number of individuals of all the species of soil microarthropods.

Dominance status of species was ascertained on the basis of RA following (Kasprzak, K. and Niedbala 1981). as has been done by Skubala (1999)
Eudominant- RA $>10 \%$
Dominant- $5.1-10 \%$
Subdominant-2.1-5.0\%
Recedent- $1.1-2.0 \%$
Subrecedent- $\mathrm{Ra}<1.0 \%$

Analysis of different community indices:

Effect of environmental factors was assessed by comparing the community structure of different zooplankton from different study zones for this purpose, some additional analysis like - index of dominance (Simpson 1949). species richness index or variety indices (Menhiniak 1964). species diversity index (Shannon and Weaver 1949) and species evenness index (Pielou 1966.) were studied by using the following expressions -

$$
\begin{aligned}
& \text { A) Species diversity index }\left(\mathbf{H}^{\prime}\right)=-(\mathrm{Pi} \\
& \log \mathrm{Pi} \\
& \text { Or }=-\left(\odot\left(n_{\mathrm{i}} / N\right) \log \left(n_{\mathrm{i}} / \mathrm{N}\right)\right.
\end{aligned}
$$

Where, $n_{i}=$ importance value for each species.

$$
\mathrm{N}=\text { total of importance values }
$$




\author{
$\mathrm{Pi}=$ importance probability for each \\ species $=n_{i} / N$
}

B) Evenness index (e) $=\mathrm{H}^{\prime} / \log \mathrm{S}$

Where , $H^{\prime}$ = diversity index

$\mathrm{S}=$ number of species

C) Simson's Diversity indices

$$
D=\frac{\sum_{i=1}^{S} n_{i}\left(n_{i}-1\right)}{N(N-1)}
$$

Where $S$ is the number of species, $N$ is the total percentage cover or total number of organisms and $n$ is the percentage cover of a species or number of organisms of a species. The value of $D$ ranges between 0 and 1 with this index, 0 represents infinite diversity and 1 , no diversity. That is, the bigger the value of $D$, the lower the diversity.

\section{D) Simson's index of diversity}

\section{$1-\mathrm{D}$}

\section{$D=$ Simsons's Diversity indices}

The value of this index also range between 0 and 1 . The greater the value, the greater the sample diversity.

\section{E) Simpson's Reciprocal Index}

$1 / D$

\section{$D=$ Simsons's Diversity indices}

The value of this index starts with 1 as the lowest possible igure. This figure would represent a community containing only one species. The higher the value, the greater the diversity.

\section{F) Species richness $(d)=S / N$}

Where, $\mathrm{S}=$ number of species all species

$$
\mathrm{N}=\text { total number of individuals of }
$$

\section{G) Species rank abundance (SRA)}

The species ranked in order of abundance. The most numerically abundant species is ranked as one (Shaw et al 1983).

\section{Results}

Different groups of soil microarthropods viz. Acarina, Collembola, Coleoptera, Diptera,
Isopoda, Hymenoptera, Arachnid, Centiped and Milliped have been recorded from the study site-1(Nayachar Island). The order Acarina included 9 families viz. Oribatulidae, Haplozetidae, Galumnidae, Oppiidae, Tectocepheidae, Trhypochthoniidae, Nanhermanniidae, Belbidae and Ceratozetidae among which maximum number of species belonged to family Oribatulidae (3 species) followed by Oppiidae (2 species), Tectocepheidae (2 species), Haplozetidae (1species), Galumnidae (1species), Trhypochthoniidae (1 species), Nanhermanniidae (1species), Belbidae (1species) and Ceratozetidae (1species). The order Collembola at the same study site was represented by 4 families. Maximum number of species ( 6 species) were found to belong under the family Entomobryidae followed by Isotomidae (5 species), Smithuridae (3 species) and Onychiuridae (1 species). The order Coleoptera at the same study site was composed of 3 families viz. Carabidae, Staphylinidae and Dytiscidae. The order Diptera was represented by two families namely Mycetophilidae and Tipulidae. Both the orders Isopoda and Hymenoptera were represented by 1 family viz. Oniscoidae (2 species) and Formicidae (4 species) respectively. The order Hymenoptera of this study site was represented by 1 family viz.. Other soil arthropods were Araneae, Chilopoda(Centiped) and Diplopoda (Milliped). The order Araneae was represented by 3 families viz. Salticidae, Pholcidae and Urocteidae (Table-1\&2).

Therefore, the study site- 1 was found to harbour 13 species of Acarina , 15 species of Collemola , 3 families of Coleoptera, 2 families of Diptera, 2 species of Isopoda, 4 species of Hymenoptera , 3 species of Araneae and 1 unidentified species each under Centiped and Milliped and thereby supported the lives of 44 microarthropod species belonging to 29 genera and 24 families including 5 families under Coleoptera and Diptera, the genera and species under those 5 families could not be identified. Besides, 2 unidentified species under Centiped and Milliped were also recorded Table-1\&2, Fig 1-7.) 
Int J Adv Life Sci Res. Volume 4(3)13-25

Table-1, Species composition of soil microarthropods at different study sites during different seasons (July 2003 to December 2005)

\begin{tabular}{|c|c|c|c|c|}
\hline Family / Species & Site-1 & Site-2 & Site-3 & Site-4 \\
\hline \multicolumn{5}{|l|}{ Family: Oribatulidae } \\
\hline Scheloribates thermophilus & + & + & + & + \\
\hline Scheloribates parvus & + & + & + & + \\
\hline Scheloribates praeincisus & + & + & + & + \\
\hline \multicolumn{5}{|l|}{ Family: Opiidae } \\
\hline Oppia sp & + & + & + & + \\
\hline Multioppia sp & + & - & - & - \\
\hline \multicolumn{5}{|l|}{ Family:Tectocepheidae } \\
\hline Tectocepheus velatus & + & - & - & - \\
\hline Tectocepheus sp & + & - & - & - \\
\hline \multicolumn{5}{|l|}{ Family: Haplozetidae } \\
\hline Xylobates seminudus & + & + & + & + \\
\hline \multicolumn{5}{|l|}{ Family: Galumnidae } \\
\hline Galumna flabellifera orientalis & + & + & + & + \\
\hline \multicolumn{5}{|l|}{ Family : Trhypochthoniidae } \\
\hline Allonothrus sp & + & - & - & - \\
\hline \multicolumn{5}{|l|}{ Family : Nanhermanniidae } \\
\hline Masthermannia sp & + & - & - & - \\
\hline \multicolumn{5}{|l|}{ Family: Belbidae } \\
\hline Metabelba obtusus & + & - & - & - \\
\hline \multicolumn{5}{|l|}{ Family : Ceratozetidae } \\
\hline Hypozetes sp & + & - & - & - \\
\hline \multicolumn{5}{|l|}{ Groups/Order : Collembola } \\
\hline \multicolumn{5}{|l|}{ Family: Isotomidae } \\
\hline Isotomurus balteatus & + & + & + & + \\
\hline Isotomiella minor & + & + & + & + \\
\hline Isotoma sp & + & - & - & - \\
\hline Proisotoma sp & + & + & + & - \\
\hline \multicolumn{5}{|l|}{ Family: Entomobryidae } \\
\hline Entomobrya sp & + & + & + & + \\
\hline Sinella sp & + & + & + & + \\
\hline Lepidocyrtus sp & + & + & + & - \\
\hline Calx sp & + & + & + & + \\
\hline Lepidocyrtus medis & + & + & + & - \\
\hline Cyphoderus sp & + & - & - & - \\
\hline \multicolumn{5}{|l|}{ Family : Smithuridae } \\
\hline Sminthurides appendiculatus & + & + & + & + \\
\hline Sminthurides $s p$ & + & - & - & - \\
\hline Sminthurides aquaticus & + & - & - & - \\
\hline \multicolumn{5}{|l|}{ Family : Onychiuridae } \\
\hline Mesaphorura choudhuri & + & - & - & - \\
\hline \multicolumn{5}{|l|}{ Family : Isotomidae } \\
\hline Cryptopygus sp & + & -- & - & - \\
\hline Groups/Order : Coleoptera & & & & \\
\hline
\end{tabular}




\begin{tabular}{|c|c|c|c|c|}
\hline Family: Carabidae & + & + & + & + \\
\hline Family Staphylinidae & + & + & + & + \\
\hline Family Dytiscidae & + & + & - & - \\
\hline \multicolumn{5}{|l|}{ Groups/Order Diptera } \\
\hline Family :Mycetophilidae & + & + & + & + \\
\hline Family: Tipulidae & + & - & - & - \\
\hline \multicolumn{5}{|l|}{ Groups/Order : Isopoda } \\
\hline \multicolumn{5}{|l|}{ Family : Oniscoidae } \\
\hline Philoscin sp & + & + & + & + \\
\hline Procellionides sp & + & + & + & + \\
\hline \multicolumn{5}{|c|}{ Groups/Order : Hymenoptera } \\
\hline \multicolumn{5}{|c|}{ Family : Formicidae } \\
\hline Monomorium destructor & + & + & + & + \\
\hline Monomorium floricola & + & + & + & + \\
\hline Monomorium latinode & + & + & + & - \\
\hline Pheidola roberti & + & - & + & - \\
\hline \multicolumn{5}{|l|}{ Other arthropods } \\
\hline \multicolumn{5}{|l|}{ Family: Salticidae } \\
\hline Marpissa sp & + & + & + & + \\
\hline \multicolumn{5}{|l|}{ Family: Pholcidae } \\
\hline Artema sp & + & + & + & + \\
\hline \multicolumn{5}{|l|}{ Family : Urocteidae } \\
\hline Uroctea $s p$ & + & + & + & - \\
\hline Centiped & + & - & - & - \\
\hline Milliped & + & - & - & - \\
\hline
\end{tabular}

Table -2. Relative abundance of different species and groups of microarthropods

\begin{tabular}{|ll|llll|}
\hline Species/Family & Abb. form & Site-1 & Site-2 & Site-3 & Site-4 \\
\hline Scheloribates thermophilus & Sch.the & $6.91 \mathrm{D}$ & $9.72 \mathrm{D}$ & $10.30 \mathrm{D}$ & $11.05 \mathrm{ED}$ \\
\hline Scheloribates parvus & Sch.par & $5.43 \mathrm{D}$ & $10.65 \mathrm{ED}$ & $7.87 \mathrm{D}$ & $7.98 \mathrm{D}$ \\
\hline Scheloribates praeincisus & Sch.pra & $4.23 \mathrm{SD}$ & $8.79 \mathrm{D}$ & $7.63 \mathrm{D}$ & $6.79 \mathrm{D}$ \\
\hline Xylobates seminudus & Xyl.sem & $4.36 \mathrm{SD}$ & $6.72 \mathrm{D}$ & $4.84 \mathrm{SD}$ & $5.19 \mathrm{D}$ \\
\hline Galumna flabellifera & Gal.fla & $3.18 \mathrm{SD}$ & $3.30 \mathrm{SD}$ & $1.69 \mathrm{R}$ & $3.72 \mathrm{SD}$ \\
\hline Oppia sp & Opp.sp & $2.97 \mathrm{SD}$ & $4.03 \mathrm{SD}$ & $1.57 \mathrm{R}$ & $1.86 \mathrm{R}$ \\
\hline Multioppia $s p$ & Mul.sp & $2.27 \mathrm{SD}$ & - & - & - \\
\hline Tectocepheus velatus & Tec.vel & $2.25 \mathrm{SD}$ & - & - & - \\
\hline Tectocepheus sp & Tec.sp & $1.63 \mathrm{R}$ & - & - & - \\
\hline Allonothrus sp & All.sp & $1.23 \mathrm{R}$ & - & - & - \\
\hline Masthermannia sp & Mas.sp & $1.59 \mathrm{R}$ & - & - & - \\
\hline Metabelba obtusus & Met.obt & $1.03 \mathrm{R}$ & - & - & - \\
\hline Hypozetes $s p$ & Hyp.sp & $0.95 \mathrm{SR}$ & - & - & - \\
\hline Isotomurus balteatus & Iso.bal & $4.51 \mathrm{D}$ & $6.41 \mathrm{D}$ & $4.48 \mathrm{SD}$ & $8.78 \mathrm{D}$ \\
\hline Isotomurus minor & Iso.min & $3.43 \mathrm{SD}$ & $7.03 \mathrm{D}$ & $5.33 \mathrm{D}$ & $5.99 \mathrm{D}$ \\
\hline Sminthurides appendiculatus & Smi.app & $3.39 \mathrm{SD}$ & $3.10 \mathrm{SD}$ & $3.87 \mathrm{SD}$ & $4.52 \mathrm{SD}$ \\
\hline Entomobrya $s p$ & Ent.sp & $2.55 \mathrm{SD}$ & $3.82 \mathrm{SD}$ & $2.42 \mathrm{SD}$ & $4.26 \mathrm{SD}$ \\
\hline Sinella $s p$ & Sin.sp & 2.83 & $1.86 \mathrm{R}$ & $2.78 \mathrm{SD}$ & $2.52 \mathrm{SD}$ \\
\hline Lepidocyrtus $s p$ & Lep.sp & $1.44 \mathrm{R}$ & $1.65 \mathrm{R}$ & $3.03 \mathrm{SD}$ & - \\
\hline Calx sp & Cal.sp & $1.95 \mathrm{R}$ & $1.44 \mathrm{R}$ & $1.57 \mathrm{R}$ & $1.73 \mathrm{R}$ \\
\hline Lepidocyrtus medis & Lep.med & $1.63 \mathrm{R}$ & $1.03 \mathrm{R}$ & $0.84 \mathrm{SR}$ & - \\
\hline Proisotoma $s p$ & Pro.sp & $1.35 \mathrm{R}$ & $1.55 \mathrm{R}$ & $1.33 \mathrm{R}$ & - \\
\hline Mesaphorura choudhuri & Mes.cho & $1.07 \mathrm{R}$ & - & - & - \\
\hline
\end{tabular}


Int J Adv Life Sci Res. Volume 4(3)13-25

\begin{tabular}{|llllll|}
\hline Sminthurides $s p$ & Smi.sp & $1.23 \mathrm{R}$ & -- & - & - \\
\hline Cyphoderus $s p$ & Cyp.sp & $1.31 \mathrm{R}$ & - & - & - \\
\hline Sminthurides aquaticus & Smi.aqu & $0.75 \mathrm{SR}$ & - & - & - \\
\hline Cryptopygus $s p$ & Cry.sp & $0.95 \mathrm{SR}$ & - & - & - \\
\hline Isotoma $s p$ & Iso.sp & $0.83 \mathrm{SR}$ & - & - & - \\
\hline Family: Carabidae & Carb & $4.51 \mathrm{SD}$ & $5.37 \mathrm{D}$ & $7.87 \mathrm{D}$ & $6.39 \mathrm{D}$ \\
\hline Family: Staphylinidae & Staph & $5.35 \mathrm{D}$ & $4.23 \mathrm{SD}$ & $2.66 \mathrm{SD}$ & $1.73 \mathrm{SD}$ \\
\hline Family: Dytiscidae & Dyti & $1.39 \mathrm{R}$ & $1.65 \mathrm{R}$ & - & - \\
\hline Family: Mycetophilidae & Myce & $4.47 \mathrm{SD}$ & $3.51 \mathrm{SD}$ & $9.69 \mathrm{D}$ & $6.25 \mathrm{D}$ \\
\hline Family:Tipulidae & Tip & $1.76 \mathrm{R}$ & - & - & - \\
\hline Philoscin $s p$ & Phil.sp & $4.23 \mathrm{SD}$ & $4.34 \mathrm{SD}$ & $6.54 \mathrm{D}$ & $6.12 \mathrm{D}$ \\
\hline Procellionides sp & Pro.sp & $1.31 \mathrm{R}$ & $1.96 \mathrm{R}$ & $1.81 \mathrm{R}$ & $1.73 \mathrm{R}$ \\
\hline Monomorium destructor & Mon.des & $1.91 \mathrm{R}$ & $1.86 \mathrm{R}$ & $3.03 \mathrm{SD}$ & $5.32 \mathrm{D}$ \\
\hline Monomorium floricola & Mon.flo & $2.27 \mathrm{SD}$ & $2.06 \mathrm{SD}$ & $2.18 \mathrm{D}$ & $1.46 \mathrm{R}$ \\
\hline Monomorium latinode & Mon.lat & $0.79 \mathrm{SR}$ & $0.93 \mathrm{SR}$ & $1.93 \mathrm{R}$ & - \\
\hline Pheidola roberti & Phe.rob & $0.59 \mathrm{SR}$ & - & $0.24 \mathrm{SR}$ & - \\
\hline Marpissa $s p$ & Mar.sp & $0.43 \mathrm{SR}$ & $0.41 \mathrm{SR}$ & $2.59 \mathrm{SD}$ & $3.99 \mathrm{SD}$ \\
\hline Artema sp & Art.sp & $0.47 \mathrm{SR}$ & $0.62 \mathrm{SR}$ & $1.09 \mathrm{R}$ & $1.19 \mathrm{R}$ \\
\hline Uroctea $s p$ & Uro.sp & $0.51 \mathrm{SR}$ & $0.62 \mathrm{SR}$ & $0.72 \mathrm{SR}$ & - \\
\hline Centiped & Centi & $1.35 \mathrm{R}$ & $1.24 \mathrm{R}$ & - & - \\
\hline Milliped & Mill & $1.11 \mathrm{R}$ & - & - & - \\
\hline
\end{tabular}

$\mathrm{E}=$ Eudominant; $\mathrm{D}=$ Dominant; $\mathrm{SD}=$ Subdominant; $\mathrm{R}=$ Recedent, $\mathrm{SR}=$ Subrecedent

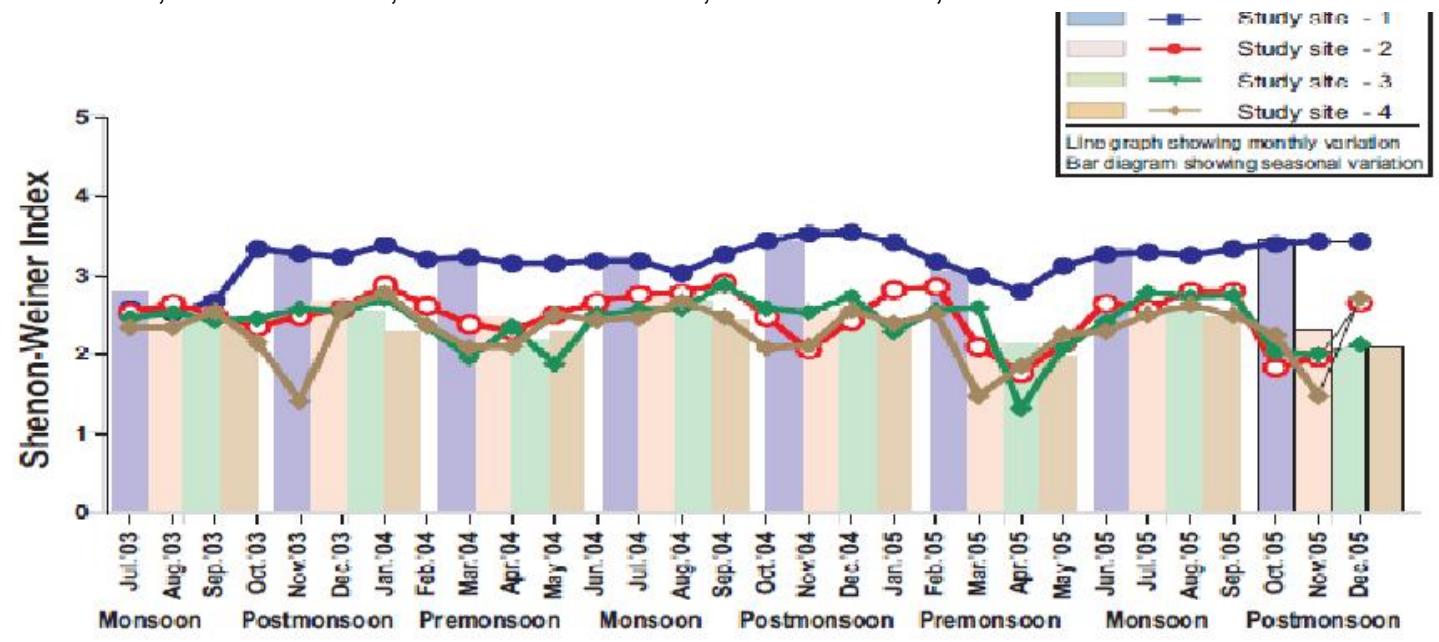

Fig-1 Monthly and seasonal fluctuation of Shennon -Weiner index at four different study sites

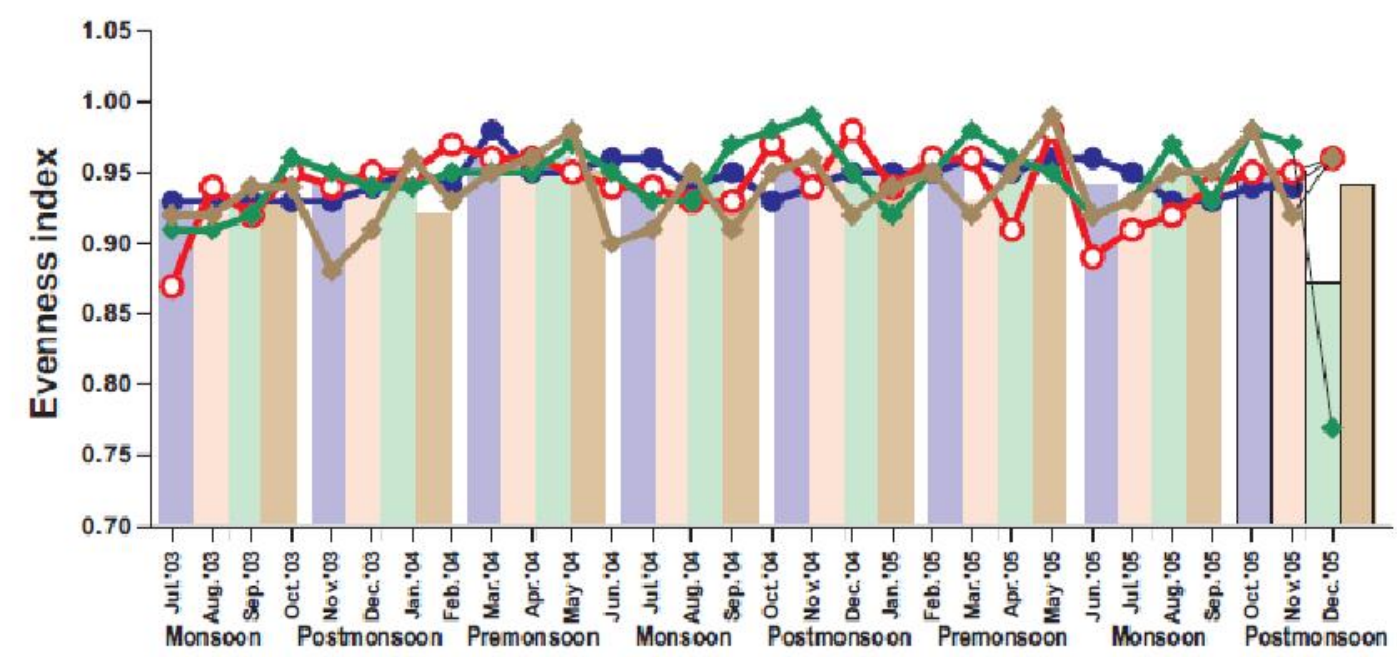

Fig-2 Monthly and seasonal fluctuation of Evenness index at four different study sites 


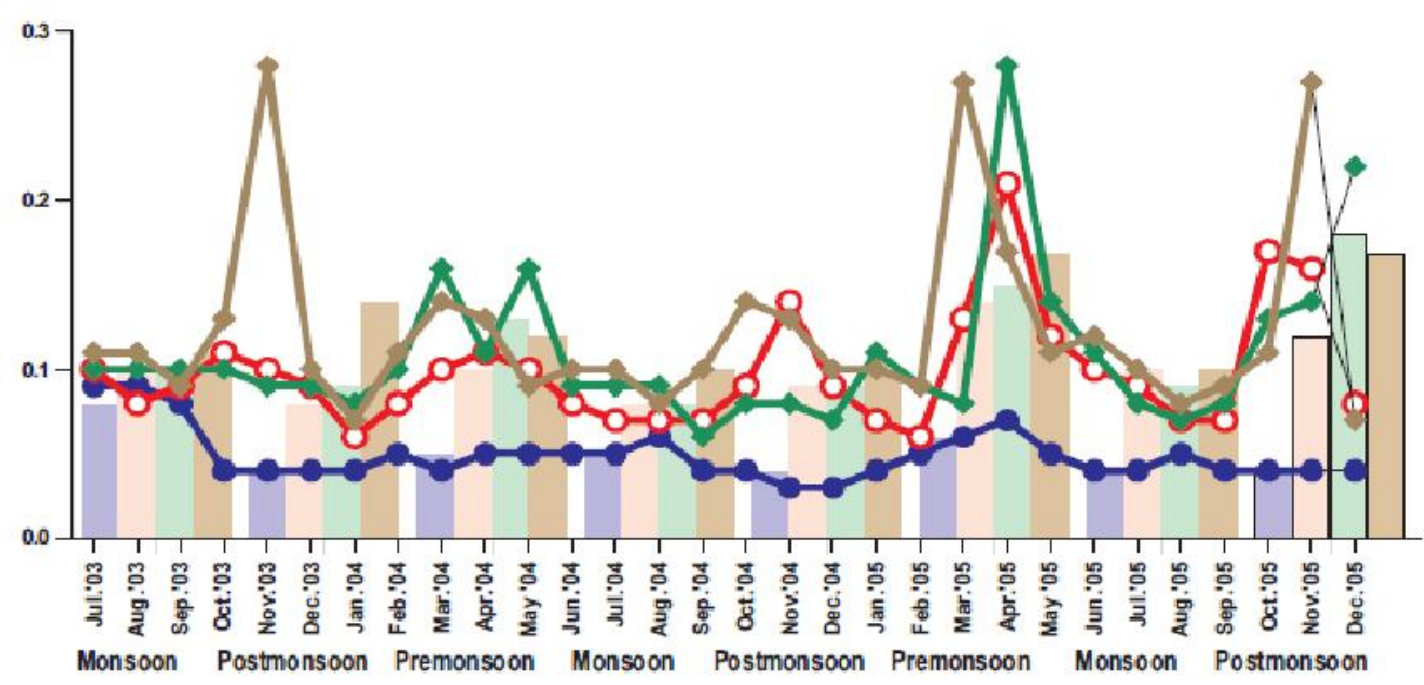

Fig-3 Monthly and seasonal fluctuation of Simson Diversity indices at four different study sites

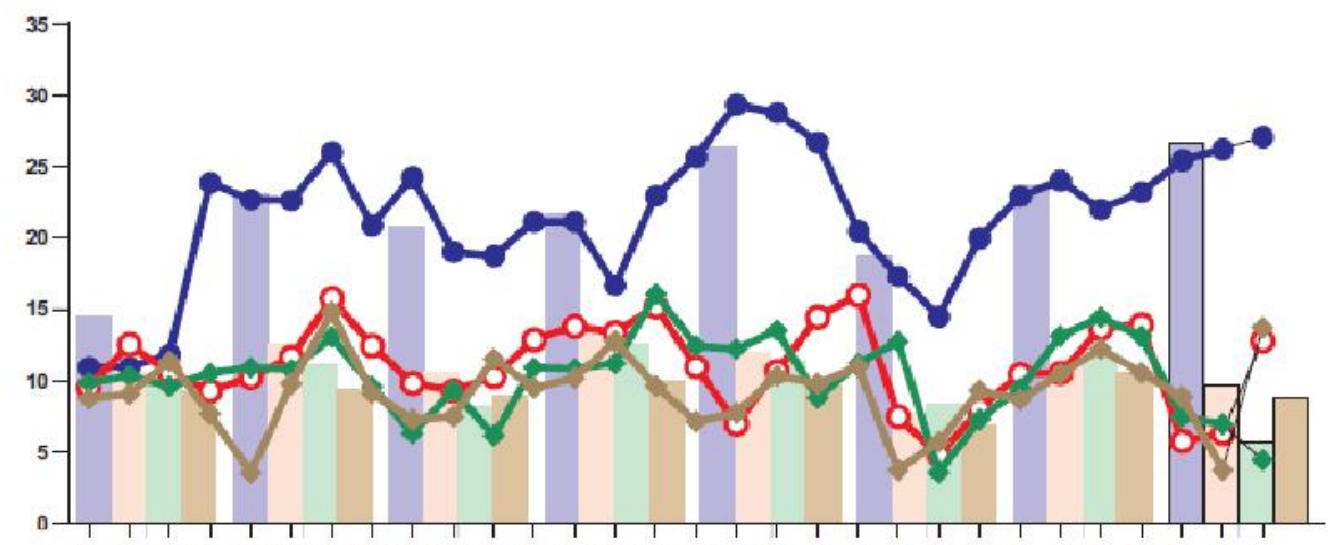

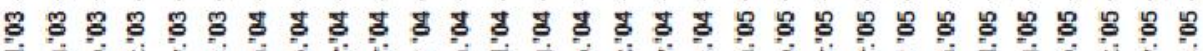

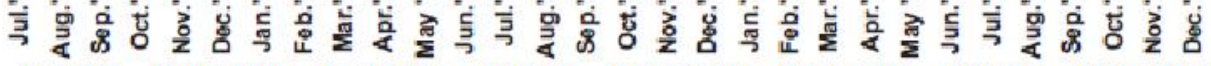
Monsoon Pastmonsoon Premonsoon Monsoon Postmonsoon Premonsoon Monsoon Postmonsoon

Fig-4 Monthly and seasonal fluctuation of Simson index of diversity at four different study sites

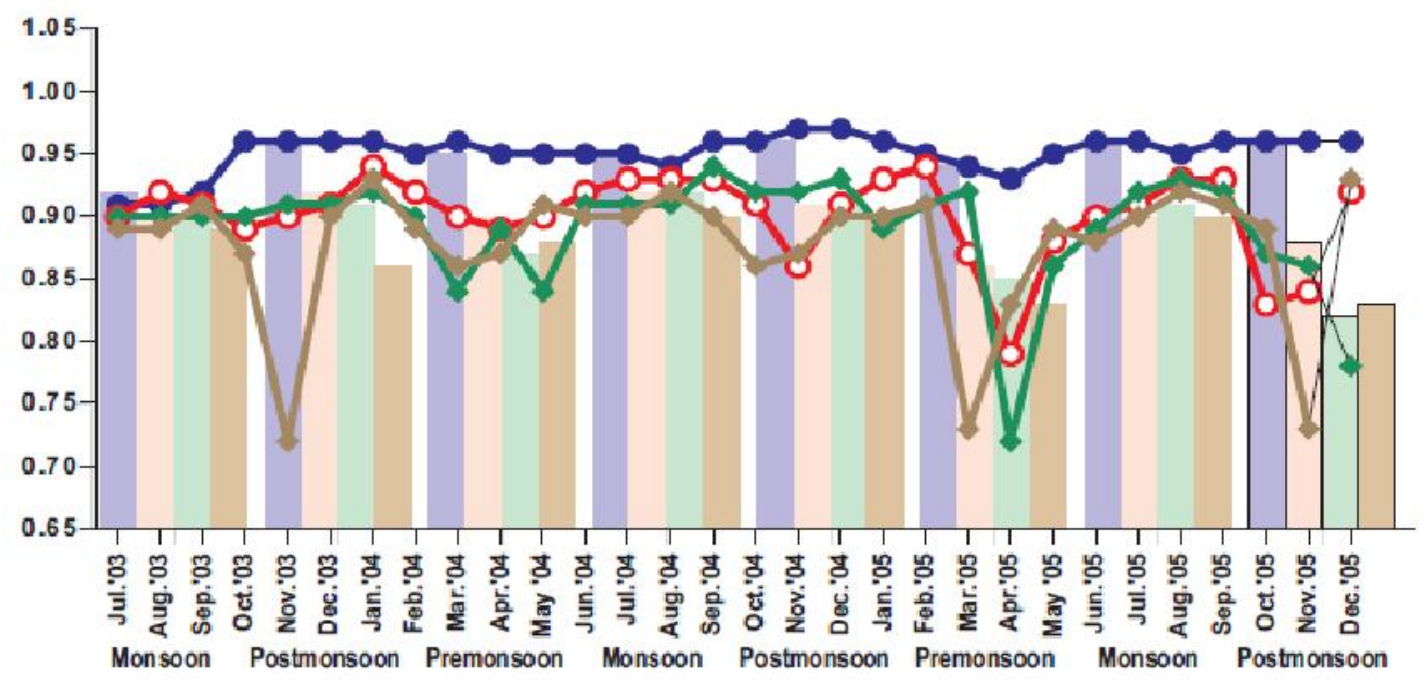

Fig-5 Monthly and seasonal fluctuation of Simson Reciprocal index at four different study sites 


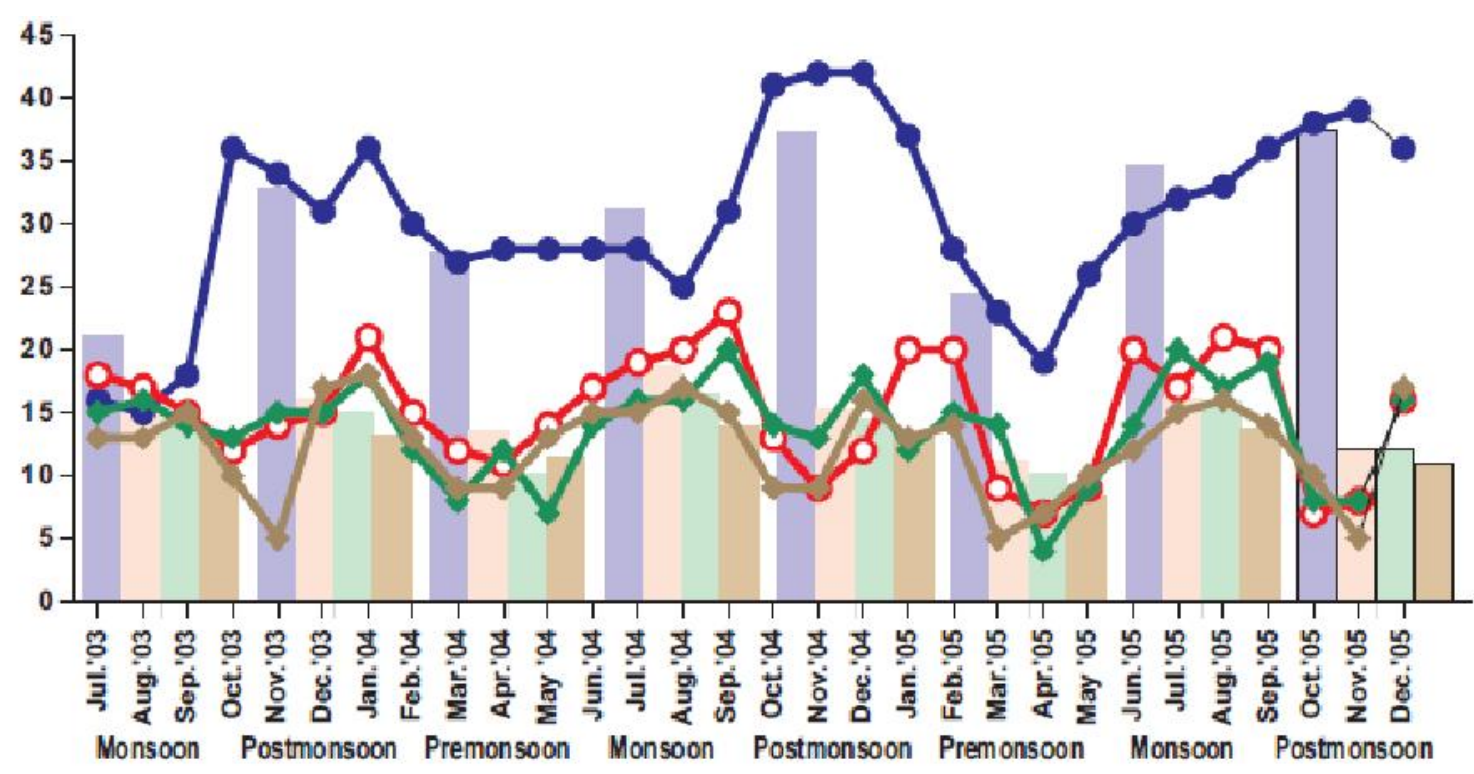

Fig-6 Monthly and seasonal fluctuation of Species Richness index at four different study sites

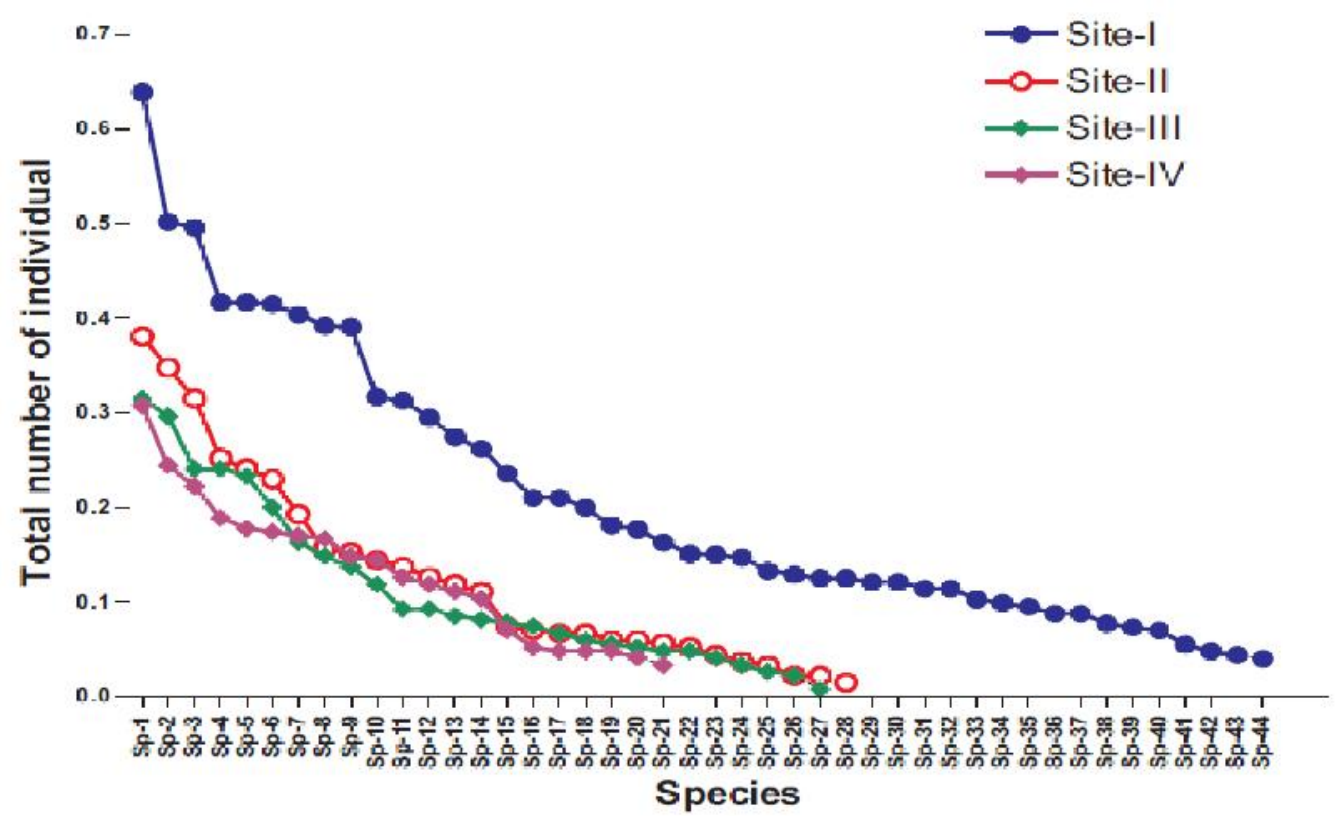

Fig-7. Dominant diversity curve

Species composition and percentage of occurrence of different soil arthropods as revealed from relative abundance analysis showed variation from one study site to others (Table-1\&2). In this study site, 4 dominanat, 14 subdominanat, 17 recedant and 9 subrecedent species were recorded. Analysis of relative abundance of 44 species belonging to 29 genera and 24 families revealed that 21 species could be categorised as dominant, subdominant, recedant, and subrecedant because of showing relative abundance greater than $2 \%$. All the 21 species which were regarded as major species and subjected to further analysis were found to occur in this site Table- $1 \& 2$

Different groups of soil microarthropods viz. Acarina, Collembola, Coleoptera, Diptera, Isopoda, Hymenoptera, Arachnid, Centiped and Milliped have been recorded from the study site-2 (Dadanpatrabarh). The order Acarina included 4 families viz. Oribatulidae, Haplozetidae, Galumnidae and Oppiidae, among which maximum number of species 
belong to family Oribatulidae (3 species) followed by Oppiidae (1species), Haplozetidae (1secies) and Galumnidae (1species). The order Collembola at the same study site was represented by 3 families of which 5 species were found to belong under the family Entomobryidae followed by Isotomidae (2 species) and Smithuridae (1 species). The order Coleoptera at the same study site was composed of 2 families viz. Carabidae and Staphylinidae. The order Diptera included 1 family namely Mycetophilidae. Both the orders Isopoda and Hymenoptera were represented by 1 family viz. Oniscoidae(2 species) and Formicidae (3 species) respectively. The other type of soil micoarthropods were represented by Araneae , Chilopoda (Centiped) and Diplopoda (Milliped). The order Areneae included 2 families viz. Salticidae and Pholcidae. Therefore, the study site-2 was found to harbour 6 species of Acarina , 9 species of Collembola , 3 families of Coleoptera, 1 family of Diptera , 2 species of Isopoda , 3 species of Hymenoptera ,3 species of Araneae and 1 species of Centiped and thereby supported the lives of 28 microarthropod species belonging to 17 genera and 16 families including 2 families under Coloptera and Diptera. The genera and species under those two families could not be identified. Two other unidentified species were recorded under Centiped and Milliped. Table 1\&2, Fig1-7.

Species composition and percentage of occurrence of different soil arthropods as revealed from relative abundance analysis showed variation from one study site to others . In this study site, 1 eudominant, 6 dominanat, 8 subdominanat, 3 recedant and 1 subrecedent species were recorded. Analysis of relative abundance of 28 species belonging to 17 genera and 16 families including 2 families under Coleoptera Diptera revealed that 19 species could be categorised as eudominant, dominant and subdominant because of showing relative abundance greater than $2 \%$. All 19 species which were regarded as major species and subjected to further analysis in this site. Table-1\&2

Different groups of soil micoarthropods viz. Acarina , Collembola, Coleoptera, Diptera, Isopoda, Hymenoptera, Arachnid, Chilopoda
(Centiped) and Diplopoda (Milliped) have been recorded from the study site-3 (Khejuree) . The order Acarina included 4 families viz. Oribatulidae, Haplozetidae, Galumnidae and Oppiidae among which maximum number of species belonged to family Oribatulidae (3 species) followed by Oppiidae (1species), Halozetidae (1species) Galumnidae (1species). The order Collembola in the same study site was represented by 3 families of which 5 species were found to belong under the family Entomobryidae followed by Isotomidae (3species) and Smithuridae (1species). The order Coleoptera at the same study site was composed of 2 families viz. Carabidae and Staphylinidae. The order Diptera included 1 family namely Mycetophilidae. Both the orders Isopoda and Hymenoptera were represented by 1 family viz. Oniscoidea (2 species) and Formicidae (2species) respectively. The other types of soil micoarthropod were represented by Araneae, Chilopoda (Centiped) and Diplopoda (Milliped). Therefore the study site-3 was found to harbor 6 species of Acarina ,9 species of Collembola , 2 families of Coleoptera, 1 family of Diptera , 2 species of Hymenoptera and 3 species of Araneae and thereby supported the lives of 27 microarthropods species belonging to 18 genera and 15 families including 3 families under Coleoptera and Diptera. The genera and species under those families could not be identified. Two other unidentified species were recorded under Centiped and Milliped. Table1\&2, Fig 1-7.

Species composition and percentage of occurrence of different soil arthropods as revealed from relative abundance analysis showed variation from one study site to others. In this study site, 1 eudominant ,7 dominanat, 9 subdominanat, 2 recedant species were recorded. Analysis of relative abundance of 27 species belonging to 18 genera and 15 families including 3 families under Coleoptera and Diptera revealed that 19 species could be categorised as eudominant, dominant and subdominant because of showing relative abundance greater than $2 \%$. All the 19 species, which were regarded as major species and subjected to further analysis in this site. Table-1\&2 
Different groups of soil micoarthropods viz. Acarina, Collembola, Coleoptera, Diptera, Isopoda, Hymenoptera, Arachnida, Chilopoda (Centiped) and Diplopoda(Milliped) have been recorded from the study site-4(Junput). The order Acarina included 4 families viz. Oribatulidae, Haplozetidae, Galumnidae and Oppiidae among which maximum number of species belong to family Oribatulidae (3 species) followed by Oppiidae (1species), Haplozetidae (1species), Galumnidae (1species). The order Collembola at the same study site was represented by 3 families of which 3 species were found to belong under the family Isotomidae followed by Entomobryidae (2species), Smithuridae (1species). The order Coleoptera at the same study site was composed of 2 families viz. Carabidae and Staphylinidae. The order Diptera included 1 family namely Mycetophilidae. Both the orders Isopoda and Hymenoptera were represented by 1 family viz.Oniscoidae(1 species) and Formicidae(2 species) respectively. The other types of soil micoarthropod were represented by Araneae, Centiped. Therefore, the study site- 4 was found to harbour 6 species of Acarina , 6 species of Collembola ,2 families of Coleoptera, 1 family of Diptera , 2 species of Isopoda , 2 species of Hymenoptera and 2 species of Araneae and thereby supported the lives of 21 microarthropod species belong to 14 genera and 14 families including 3 families under Coleoptera and Diptera. The genera and species under those families could not be identified besides 1 unidentified species under Centiped. Table-1\&2, Fig 1-7.

Species composition and percentage of occurrence of different soil arthropods as revealed from relative abundance analysis showed variation from one study site to others. In this study site, 1eudominant, 9 dominanat, 6 subdominanat, 2 recedant species were recorded. Analysis of relative abundance of 21 species belonging to 14 genera and 14 families including 3 families under Coleoptera and Diptera revealed that 18 species could be categorised as eudominant, dominant and subdominant because of showing relative abundance greater than $2 \%$. All the 18 species, which were regarded as major species and subjected to further analysis of this site. Table- $1 \& 2$.

\section{Discussion}

The present study was based on the field survey of four selected contrasting ecological habitats of Midnapore coast, West Bengal, India over a period of 30 months (July2003 December 2005). This study included faunal composition, species distribution, and population dynamics and community structure of different microarthropod fauna in relation to various environmental parameters through different months, seasons and years. Four study sites viz. Study site-1 (Nayachar Island), Study site-2 (Dadanpathrabhar), Study site-3 (Khejuree) and Study site-4 (Junput) of Midnapore (East) coastal ecosystem were selected to record the differences among them relating to species composition, population dynamics, ecological condition and community structure of soil microarthropods. The soil microarthropod fauna recorded here belong to six groups like Acarina, Collembola, Coleoptera, Diptera, Isopoda, Hymenoptera and other soil microarthropods. Soil microarthropods differed in their diversity and density from season to season. The number of groups occurring in the different sampling sites also varied maximum was recorded from study site- 1 and that of minimum was from study site-4. Species composition and percentage of occurrence of different soil microarthropods as revealed from relative abundance analysis showed variation from one study site to others. At study site-1, 4 dominant (3.1-10\%), 14 subdominant $(2.1-5 \%), 17$ recedent (1.1-2.0\%) and 9 subrecedent $(R A<1.0 \%)$ species were recorded. At study site-2, 1 eudominant (Ra>10\%), 6 dominant (5.1-10\%), 8 subdominant $(2.1-5 \%), 9$ recedent $(1.1-2 \%)$ and 4 subrecedent (RA,1.0\%) were found. At study site-3, 1 eudominant (RA>10\%), 7 dominant (5.1-10\%), 9 subdominant (2.1$5.0 \%), 7$ recedent $(1.1-2 \%)$ and 3 subrecedent species were observed. At study site-4, 1 eudominant (RA $>10 \%)$, 8 dominant (5.1-10\%), 6 subdominant $(2.1-5 \%), 6$ recedent $(1.1-2 \%)$ species were recorded. Analysis of relative abundance of 44 species belonging to 29 genera and 24 families revealed that of which 21 species could be included in the categories of eudominant (RA $>10 \%)$, dominant $(5.1-10 \%)$ 
and subdominant (2.1-5\%). These 21 species regarded as major species. A total of 21 species of soil microarthropods were studied in details with regard to seasonal population fluctuation, variation in their community structure, relationships with physiochemical parameters of soil, life cycle patterns and their functional role in the ecosystem (Dey et al 2010,2008,2006,2005, Dey and Hazra 2020) These studies contain results of an ecological study involving the impact of different soil factors and some climatological factors on soil microarthropods population from four different selected study sites of coastal tract (Sjoling et al 2005, Gillikin \& Verheyden 2005, Chapman 1986) . Soil factors like $\mathrm{pH}$, organic carbon, salinity, total nitrogen, total phosphorus, available potassium and climatological factors like temperature, rainfall, humidity were taken into consideration. Soil microarthropods and their interaction with these parameters were also studied. The population density of different major species showed wide range of variation through different months, seasons and years (July2003 to December 2005). Moreover, the population reached its highest peak during postmonsoon at study site- 1 while other threestudy sites-2, 3 and 4 experienced highest peaks during monsoon( Dey et al 2012, Dey and Hazra 2020) The lowest population density of soil microarthropods species was observed during premonsoon at study site-1 and that of postmonsoon at study sites-2, 3 and 4 . In present study, it was found that in different seasons, numbers of species of soil microarthropods were found to increase, along with the increase of the value of species diversity indices. Results of diversity indices revealed that, in study site-1, the postmonsoon season registered the higher species diversity and other three study sites documented the higher species diversity during monsoon. Most of the predominant soil microarthropodal forms encountered here found to exhibit a single peak in a year. The pattern of seasonal variation appeared to be different in different forms, which perhaps indicated the existence of different breading periods. On the other hand, population fluctuation of some species have shown difference in abundance or peak population one site to other sites which was supposed to be due to the effect of soil type, environmental and edaphic parameters of a particular site (Raffaelli \& Hawkins 1996, Gillikin \& Verheyden 2005, Dey et al 2005,2007). The soil microarthropods like Scheloribates thermophilus, Scheloribates parvus, Scheloribates praeinasus, Xylobates semnudes, Isotomurus balteatus, Sminthurides appendiculatus, Entomobrya $s p$, Sinella sp, Lepidocyrtus sp, Family Carabidae, Staphylinidae, Mycetophilidae, Philoscias sp, Monomorium destructor, Monomorium floricola, Marpissa sp seemed to have wider range of tolerance for various habitats in the present study, therefore they were "ubiquist" while 3 forms of soil microarthropods were found to be restricted to any single site of four contrasting habitats (Multioppia $s p$, Tectocepheus velatus, Lepidocyrtus $s p$ ) and such as they were "Stenocious". Several community organization analysis such as relative abundance, richness, species diversity index and evenness index were also computed to study the detailed soil microarthropods community structure. The cluster analysis has also been carried out to show the degree of similarities between the different groups of soil microarthropods of different study sites. In the present study, Study site- 1 exhibited both higher of species richness and species evenness as compared to other three study sites. From the comparison of four study sites, it was found that the pattern of variation with regard to both of species evenness and richness were similar in nature but higher species value at study site-1 which was supposed to be due to the undisturbed condition of this study site which was away from any anthropogenic disturbance.

\section{Conclusion}

Soil microarthropods help ecosystem functioning by way of imparting an important role in food-chain, food web system vis-à-vis in trophic relationships and also help nutrient cycling as decomposer.

\section{Acknowledgments}

The authors wish and sincerely thank to Director, Zoological Survey of India, Kolkata for providing necessary laboratory facilities. Thanks are also Dr. A.K.Sanyal, Dr. 
G.P.Mandal, Dr. Bulganin Mitra, Sri S.S.Saha, Sri K.K.Suman, Sri K.L.Nath, Sri B.K.Halder and other subject specialists of Zoological Survey of India. Thanks to Calcutta port trust

\section{References}

Chakraborty S.K. and A. Choudhury, (1995). Population density and biomass of intertidal macrozoobanthos of sagar Island, Sundarbans, India . In National Workshop on Biomass availability and assessment techniques. Techinal Paper; INCOR, Visakhapatnam, BioEnergy Society of India pp1-6.

Chapman, S.B (1986). Production Ecology and Nutrient Budgets In,Moore ,P.D \& Chapman, S.B . Methods in plant ecology. Second Edition, Oxford, Blackwell Scientific Publication. 1-59pp.

Curry, J.P. (1971). Seasonal and vertical distribution of the Arthropods fauna of an old grassland soil. Scientific Proceeding, Royal Dublin Society, Series B 3:49-71.

Dey .M.K, A.K.Hazra and S.K.Chakraborty (2010) Functional Role of Microarthropods in Nutrient Cycling of Mangrove -Estuarine Ecosystem of Midnapore Coast of West Bengal, India. International Journal of Environmental Technology and Management. Vol12 No1; 67-84. ISSN-14662132.

Dey M,K, A.K.Hazra and G.P.Mandal (2005) Diversity and Distribution of Arthropods Fauna In Relation To Mangrove Vegetation on A Newly Emerged Island On The River Hooghly, West Bengal. Rec.Zool.Surv.India. 104(Part3-4); 99-102. ISBN-81-8171-0649.

Dey M.K \& A.K.Hazra (2020). Litter decomposition Study (Aveicennia offcinalis) with the help of soil arthropods. W.r.f to Nayachar Island, West Bengal, India . International Journal of Science and Research. ISSN: 2319-7064. Vol 9; Issue 10 Oct.

Dey M.K \& A.K.Hazra (2020). Heritiera fomes (Buch-Hum) leaf litter decomposition of newly emerged virgin deltaic Island (Nachar) located on north eastern part ofMidnapore coast of West Bengal . International Journal of Creative research thoughts. ISSN 2320-2882. Vol-8.

Dey M.K \& A.K.Hazra (2020). Litter fall and decomposition of Mangrove species (Excoecaria agallacha ) in a newly emerged Island (Nayachar ). West Bengal. India; w.r.f Soil microarthropods. International Journal of Innovative Science and Research Technology : ISSN No 2456-2165; Vol 5. authority, Govt. of India providing valuable necessary arrangement in this research.

\section{Conflicts of Interest}

The authors declare no conflict of interest.

Dey M.K, A.K.Hazra and A.K.Sanyal (2005). Effect OF Soil Salinity On The Population Dynamics of Soil Arthropods Fauna at Nayachar Island Of MidnaporeDistrict .Environment \& Ecology: 23(4); 767-769.ISSN-0970-0420.

Dey M.K, A.K.Hazra and S.K.Chakraborty (2008) Diversity of Microarthropods and the Plant Litter Decomposition in the Coastal Tract of East Midnapore District, West Bengal, India. Zoological Research in Human Welfare :20; 207-226 . ISSN0373-5893. Kasprzak

Dey M.K, A.K.Hazra and S.K.Chakraborty (2012) Diversity Of Mangrove Litter Inhabiting Microarthropods with Special Reference To Their Functional Role in Midnapore(East) Cosast, West Bengal, India . Biodiversity \&Taxonomy ,Narendra Publishing House . pp29-42. ISBN 978-9380428925

Dey M.K, A.K.Hazra and S.K.Chakrabory (2007) Soil Micro-Arthropods Population in Alluvial and Coastal Soil InMidnaporeDstrict With Special Reference To Relative Abundance. Rec.Zool.Surv.India; 107(Part-4):93-99. ISBN 818171-0649.

Dey.M.K, A.K.Hazra and S.K.Chakraborty (2006) Ecology of Coliform Bacteria in a Heavy Metals Contaminated River at Midnapore District area, West Bengal. Rec.Zool.Surv.India(Part-3); 1-8. ISBN-81-8171-0649.

Gillikin, D. \& Verheyden, A. (2005). "Rhizophora mucronata Lamk. 1804". A field guide to Kenyan mangroves

Kasprzak, K. and Niedbala, W. (1981). Wskazniki biocenotyczne stosowane Przy porzadkowaniu analize danych $\mathrm{W}$ budaniach ilosciowych. In Metody Stosowane W. Zoologii gleby (Gorny, M\& Greun, L.Eds). PWN. Warszawa 397-416.

Luxton, M. (1966). Laboratory studies on the feeding habitats of saltmarsh Acarina, with note on their behavior. Acarologia, 8: 163-175.

Macfadyen, A. (1955). A comparison of methods for extracting soil arthropods, 315-332. In: Soil Zoology (D.K.McE Kevan, Ed.) Butterworth, London. 
Int J Adv Life Sci Res. Volume 4(3)13-25

Menhiniak, E.F. (1964). A comparison of some species diversity indices applied to samples of field insects. Ecology. 45: 859-861.

Monleon, V.J. and Kermit Cromak Jnr. (1996). Long term effects of prescribed underburning on litter decomposition and nutrient release in pondarosa pine stsnds in central Oregon. Forest Ecology and Management. 81:143-152.

Newel, K. (1984). Interaction between two decomposer Basidiomycetes and a collembolans under Sitka spruce: Distribution, Abundance and selective grazing, Soil. Biology and Biochemistry, 16: 227-233.

Pielou, E.G. (1966.) The measurement of diversity in different types of biological Collections. Journal of theoretical Biology, 13: 131-144.
Raffaelli, D \& Hawkins, S (1996). Inertidal Ecology . $1^{\text {st }}$ edition, Londres, Chapman and Hall .356pp.

Shannon C.E and W. Weaver, (1949). The Mathematical Theory of Communications Illinois University Press Urbana.

Simpson, E.H. (1949). Measurement of diversity. Nature 163-688.

Skubala, P. (1999). Colonization of dolomitic dump by oribatid mites (Acari, Oribatida), Pedobiologia, 43: 145-154. 